\title{
Nitrogen transformation during gasification of livestock compost over transition metal and
}

\section{Ca-based catalysts}

Jing-Pei Cao ${ }^{\text {a,b* }}$, Xin Huang ${ }^{a}$, Xiao-Yan Zhao ${ }^{a^{* *}}$, Xian-Yong Wei ${ }^{a}$, Takayuki Takarada ${ }^{b}$

${ }^{a}$ Key Laboratory of Coal Processing and Efficient Utilization, Ministry of Education, China University of Mining \& Technology, Xuzhou 221116, Jiangsu,China

b Division of Environmental Engineering Science, Gunma University, 1-5-1 Tenjin-cho, Kiryu 376-8515, Japan

\section{Abstract}

Catalytic gasification of a pig compost (PC) was investigated over transition metal catalysts (TMCs, including limonite, $\mathrm{CoMo} / \mathrm{Al}_{2} \mathrm{O}_{3}, \mathrm{Ni} / \mathrm{Al}_{2} \mathrm{O}_{3}$, and nickel loaded on lignite char) and Ca-based catalysts (dolomite and $\mathrm{CaO}$ ) in a two-stage fixed-bed reactor to understand the effects of catalyst, temperature, and steam on nitrogen distributions. Non-catalytic thermal decomposition (TD) of PC volatiles below $750{ }^{\circ} \mathrm{C}$ is not effective for decomposing the entire volatile nitrogen species (VNSs) to $\mathrm{N}_{2} \cdot \mathrm{NH}_{3}$ was found to be the predominant nitrogenous gas under inert conditions used in this investigation, and its yield increased with raising TD temperature. The N yield in $\mathrm{HCN}$ is lower than $5 \%$ below $550{ }^{\circ} \mathrm{C}$, and sharply increased to $13.9 \%$ at $750{ }^{\circ} \mathrm{C}$ due to TD of volatiles. Most of VNSs were converted to $\mathrm{N}_{2}$ over TMCs, especially over Ni-based ones. The TMCs proved to be quite active not only for tar reduction, but also for VNSs decomposition at $450-650{ }^{\circ} \mathrm{C}$. On the contrary, CaO-based catalysts, especially dolomite, significantly promoted the conversion of VNSs to $\mathrm{NH}_{3}$. Ni/Al $\mathrm{O}_{3}$ effectively promoted the conversion of $\mathrm{NH}_{3}$ and $\mathrm{HCN}$ to $\mathrm{N}_{2}$ at $550{ }^{\circ} \mathrm{C}$. Steam introduced mainly prevented $\mathrm{HCN}$ decomposition over dolomite and coke deposition over $\mathrm{Ni} / \mathrm{Al}_{2} \mathrm{O}_{3}$. This study provides a basic insight into the nitrogen transformations during catalytic gasification of PC, which would benefit the clean utilization of PC as an energy source.

Keywords: Pig compost; Gasification; Nitrogen transformation; Transition metal; $\mathrm{NH}_{3}$; Ca-based catalyst

\footnotetext{
${ }^{*}$ Corresponding author. Tel.fax: +86 516 83591059. E-mail address: beyondcao@hotmail.com (J.-P. Cao)

${ }^{* *}$ Corresponding author. Tel.fax: +86 516 83591059. E-mail address: zhaoxiaoyan@cumt.edu.cn (X.-Y. Zhao)
} 


\section{Introduction}

The disposal of livestock manure (LSM) becomes a growing problem due to its high potential for pollution and increasing production. In general, LSM is a potential source of pathogen-containing wastes, which emits ammonia, greenhouse gases, and odorous compounds, causing water contamination and air pollution. The traditional disposal routes of LSM, including agricultural application and landfill, are facing more and more pressure due to land limitations and stringent regulations [1,2]. Thus, it is important to develop a cost-effective and ecofriendly solution to replace those traditional disposal technologies.

Alternatively, using LSM as a biomass for energy production via biological and thermochemical conversion technologies is regarded as an environmentally acceptable disposal route with potential financial benefits. Anaerobic digestion is one of biological means for decomposing LSM in an oxygen-free environment, and has the advantage of producing biogas [3]. Several thermochemical conversion technologies, including pyrolysis, gasification, combustion, and liquefaction, are currently under development $[3,4]$. Among these processes, gasification is an efficient method for converting biomass wastes to energy or syngas [4,5]. Catalytic gasification (CG) of LSM successfully produced the hydrogen-rich gas over Ni-based catalysts (NBCs) [6-10]. However, LSM usually contains large amounts of organonitrogen species, which are converted to $\mathrm{NO}_{x}$ precursors such as $\mathrm{NH}_{3}, \mathrm{HCN}$, and nitrogen in tar $\left(\mathrm{N}_{\text {tar }}\right)$ during pyrolysis and then to $\mathrm{NO}_{x}$ and $\mathrm{N}_{2} \mathrm{O}$ during gasification and combustion, causing significant environmental pollution $[11,12]$. It is of great significance to understand the release behaviours of nitrogen-containing species (NCSs) and their transformation during pyrolysis and decomposition of LSM volatiles. There is much information available on the formation and decomposition of NCSs during pyrolysis and gasification of coals and biomass, but little information on LSM is available.

Many catalysts, such as dolomite, $\mathrm{CaO}$, olivine, alkali metals, transition metals, and activated carbon-supported catalysts, have been used for biomass gasification [13,14]. Among them, the transition metal catalysts (TMCs), especially nickel-, iron-, and cobalt-based ones, are active for 
biomass tar decomposition to produce hydrogen-rich gas and syngas [6-9,13,14]. Limonite is a naturally occurring iron ore with a high iron content and was used for tar decomposition [13]. Dolomite is widely used as the secondary catalyst to minimize tar content in biomass gasification, and the presence of $\mathrm{CaO}$ in dolomite might be responsible for its activity for tar conversion [13].

In the present study, we focus on CG of a pig compost (PC) over TMCs and Ca-based catalysts (CBCs) in a two-stage fixed-bed quartz reactor (TSFBQR). The effects of catalyst, temperature, and steam on the nitrogen distributions were investigated. Prior to the CG experiments, nitrogen distribution during thermal decomposition (TD) was first studied in this work.

\section{Experimental}

\subsection{Materials}

The PC was obtained from a piggery in the Gunma Prefecture, Japan. It was pulverized to pass through a 16 -mesh sieve $(<1.18 \mathrm{~mm})$ followed by oven-dried at $107^{\circ} \mathrm{C}$ for $24 \mathrm{~h}$ and then storage in an airtight container before use. Ultimate analysis was conducted with a Leco CHN-2000 elemental determinator and a Leco SC-432 sulfur determinator. High calorific value (HCV) was determined with a Shimadzu CA-4PJ auto-calculating bomb calorimeter. Table 1 summarizes the main characteristics of the PC sample.

Four TMCs, including commercial $\mathrm{Ni} / \mathrm{Al}_{2} \mathrm{O}_{3}$ (No. C13-4, Süd-Chemie Catalysts Japan, Inc., Ni loading $20 \pm 2$ wt. $\%, 0.5-1.0 \mathrm{~mm})$ and $\mathrm{CoMo} / \mathrm{Al}_{2} \mathrm{O}_{3}\left(\mathrm{SC} 20-6\right.$, $\mathrm{CoO}: 3.0-4.0$ wt.\%, $\mathrm{MoO}_{3}$ : 13.0-15.0 wt.\%), a limonite ore (Indonesian), and nickel loaded on Loy Yong lignite char (Ni/LYLC, Ni loading $9 \pm 1$ wt.\%) [15], and two CBCs (i.e., $\mathrm{CaO}$ and calcined dolomite) were used for the CG. The CBCs were calcined at $1200{ }^{\circ} \mathrm{C}$ for $1 \mathrm{~h}$ before use. The main component in calcined limonite and dolomite was determined by a Shimadzu EDX-700 energy dispersive X-ray spectrometer and the results are shown in Table 2. A Mac Science M03XHF ${ }^{22}$ X-ray diffraction (XRD) and BEL BELSORP-max constant volume adsorption apparatus were used for the catalyst characterization. The Ni loadings and $\mathrm{Ni}$ particle sizes (NPSs) in the $\mathrm{Ni} / \mathrm{Al}_{2} \mathrm{O}_{3}$ and $\mathrm{Ni} / \mathrm{LYLC}$ were determined as reported previously [16]. The main characteristics of the catalysts are shown in Table 3. 


\subsection{Gasification}

CG was performed in a TSFBQR as reported previously [8]. The reactor tube $(20 \mathrm{~mm}$ i.d. and $900 \mathrm{~mm}$ long) has two stages and is heated by two electrical furnaces, respectively. Argon was used as the carrier gas with a flow rate of $120 \mathrm{~mL} / \mathrm{min}$. During the experiment, $1 \mathrm{~g}$ PC was put on the first stage and $3 \mathrm{~g}$ catalyst was put on the second stage for catalytic decomposition of the tarry species. When $\mathrm{Ni} / \mathrm{Al}_{2} \mathrm{O}_{3}$, limonite, and $\mathrm{CoMo} / \mathrm{Al}_{2} \mathrm{O}_{3}$ were used, the second stage was heated up to $650{ }^{\circ} \mathrm{C}$ for reducing the catalyst with $\mathrm{H}_{2}$ for $1 \mathrm{~h}$. After $\mathrm{H}_{2}$ was replaced by Ar completely, the second stage was set at a prescribed temperature between 450 and $750{ }^{\circ} \mathrm{C}$. Then the first stage was heated to $900{ }^{\circ} \mathrm{C}$ at $10{ }^{\circ} \mathrm{C} / \mathrm{min}$ and held at that temperature for $0.5 \mathrm{~h}$. The volatiles from PC pyrolysis were streamed into the second stage for decomposition. For steam gasification, steam was fed through a branch inlet, which was welted onto the main reactor at a position of $50 \mathrm{~mm}$ below the biomass pyrolysis bed. When the first stage temperature reached to $100{ }^{\circ} \mathrm{C}$, steam was generated and flowed into the reactor for the PC volatile gasification at the second stage. Steam partial pressure in the second stage was controlled at $30 \mathrm{kPa}$ and the total flow rate of the feed gas was kept at 120 $\mathrm{mL} / \mathrm{min}$. The gaseous products (GPs) passed through two tar traps with deionized water (DIW) cooled with an ice-water bath for water-soluble oil (WSO) collection, while the noncondensable gases were collected in a gas bag for GC analysis. For the non-catalytic test, sand was put on the second stage to the same bed height as the catalytic experiment. Soot deposited on the catalysts and reactor wall was burned out at $600{ }^{\circ} \mathrm{C}$ under an $\mathrm{O}_{2}$ flow rate of $80 \mathrm{~mL} / \mathrm{min}$ for $1 \mathrm{~h}$ and collected in another gas bag. When Ni/LYLC was used, the catalyst was moved out and only the soot deposited on the reactor wall was determined.

\subsection{Characterization}

Total carbon and nitrogen contents in char recovered were determined with a Leco-2000 elemental determinator. $\mathrm{H}_{2}$ and $\mathrm{N}_{2}$ in GPs were analyzed with a Shimadzu GC/14B GC/TCD, while the carbonaceous gases were analyzed with a Shimadzu GC/14B GC/FID equipped with a methane converter to convert carbon oxides into detectable $\mathrm{CH}_{4}$. Total organic carbon (TOC) and total 
nitrogen $(\mathrm{TN})$ contents in WSO were determined with a Shimadzu TOC-V $\mathrm{CPH}_{\mathrm{CP}}$ TOC-TN analyzer. $\mathrm{NH}_{3}$ and $\mathrm{HCN}$ absorbed in DIW were quantified with a TOA DKK ICA-2000 ion chromatograph as reported [12].

\section{Results and discussion}

\subsection{Characteristics of the catalysts}

As shown in Fig. 1, metallic nickel can be confirmed in Ni/LYLC by XRD analysis. Previous investigations $[9,15]$ showed that the fine nickel particles dispersed quite well in Ni/LYLC. The average crystallite size of the nickel particles was obtained by Scherrer formula from the peak around $44^{\circ}$. The NPSs of Ni/LYLC and $\mathrm{Ni} / \mathrm{Al}_{2} \mathrm{O}_{3}$ was estimated to be 6.9 and $10.3 \mathrm{~nm}$, respectively. In general, a higher NPS leads to a lower active surface/volume ratio and the decline in the activity of the NBC. In addition, Ni/LYLC has a higher BET surface area and a smaller pore size in comparison with $\mathrm{Ni} / \mathrm{Al}_{2} \mathrm{O}_{3}$, as listed in Table 3. The results show that $\mathrm{Ni} / \mathrm{LYLC}$ has a good textural characteristic and is expected to be active for CG. Limonite is regarded as an attractive alternative to the commercial Ni catalysts, due to the advantage in less expensive and abundant resource [13]. The limonite is mainly composed of goethite $(\mathrm{FeOOH})$ with an iron content of $65.0 \%$ (expressed as metal oxides, as exhibited in Fig. 1 and Table 2). Iron oxide was converted to metallic iron after reduction at $650{ }^{\circ} \mathrm{C}$. The BET surface area decreased from 149 to $46 \mathrm{~m}^{2} / \mathrm{g}$, while the pore size increased to $16.6 \mathrm{~nm}$, after reduction at $650{ }^{\circ} \mathrm{C}$. The commercial $\mathrm{CoMo} / \mathrm{Al}_{2} \mathrm{O}_{3}$ has $\mathrm{CoO}$ and $\mathrm{MoO}_{3}$ contents of 3.0-4.0 wt.\% and 13.0-15.0 wt.\%, respectively. $\mathrm{CoMo} / \mathrm{Al}_{2} \mathrm{O}_{3}$ has a relatively high surface area of $230 \mathrm{~m}^{2} / \mathrm{g}$ and can provide an enough reaction area, which is favorable for use in volatile reforming. As listed in Tables 2 and 3, the main component of the calcined dolomite is $\mathrm{CaO}$, and this catalyst shows a mesopores characteristic with relatively low surface area. The calcined commercially available $\mathrm{CaCO}_{3}$ was reported to possess more porosity in the range of mesopore region $(2-50 \mathrm{~nm})$ [17]. The $\mathrm{CaO}$ used in this study has a larger pore size and lower surface area in comparison with the calcined dolomite.

\subsection{Non-catalytic test}


As Fig. 2 shows, the nitrogen distribution, especially for $\mathrm{NH}_{3}$ and $\mathrm{HCN}$, is strongly affected by TD temperature. About $21.5 \%$ of nitrogen in PC $\left(\mathrm{N}_{\mathrm{PC}}\right)$ was found to be retained in char $\left(\mathrm{N}_{\text {char }}\right)$, while the rest of the nitrogen was released as nitrogen in volatiles $\left(\mathrm{N}_{\text {volatile }}\right)$, which was found in the form of $\mathrm{N}_{\mathrm{tar}}, \mathrm{NH}_{3}, \mathrm{HCN}$, and $\mathrm{N}_{2}$ (Eq. (1)).

$$
\begin{aligned}
& \mathrm{N}_{\text {volatile }} \rightarrow \mathrm{N}_{\mathrm{tar}}+\mathrm{NH}_{3}+\mathrm{HCN}+\mathrm{N}_{2} \\
& \mathrm{~N}_{\mathrm{tar}} \rightarrow \mathrm{NH}_{3}+\mathrm{HCN}+\mathrm{N}_{2}
\end{aligned}
$$

$\mathrm{NH}_{3}, \mathrm{HCN}$, and $\mathrm{N}_{2}$ were detected as the nitrogen-containing GPs and the yields of $\mathrm{NH}_{3}$ and $\mathrm{HCN}$ increased with raising temperature via the reforming reactions (Eq. (2)), while no obvious change of $\mathrm{N}_{2}$ yield can be found. $\mathrm{NH}_{3}$ is the main NCSs under inert conditions used in this investigation. Even the second stage was set at room temperature (RT), significant formation of $\mathrm{NH}_{3}\left(26.7 \%\right.$ of $\left.\mathrm{N}_{\mathrm{PC}}\right)$ was observed. Pyrolysis of proteins as model compounds revealed that the composition of amino acids in proteins has a remarkable impact on the formation of $\mathrm{NH}_{3}$ [18]. $\mathrm{PC}$ usually contains significant amount of proteins, most of which can be pyrolyzed at $400-500{ }^{\circ} \mathrm{C}$ [11]. Therefore, the formation of $\mathrm{NH}_{3}$ should be related to its high protein content. The yield of $\mathrm{NH}_{3}$ remained at a level in the temperature range up to $450{ }^{\circ} \mathrm{C}$ and then increased sharply to $37.9 \%$ by raising temperature to $650{ }^{\circ} \mathrm{C}$. Further raising the temperature to $750{ }^{\circ} \mathrm{C}$ caused a decrease in the $\mathrm{NH}_{3}$ yield to $30.5 \%$. Similar result was reported for TD of $\mathrm{NH}_{3}$ [19]. The yield of nitrogen in WSO $\left(\mathrm{N}_{\mathrm{WSO}}\right)$ is quite low when the second stage was not heated. In this case, the nitrogen loss calculated by difference is $c a .31 .8 \%$, which should be in water-insoluble portion (WISP) or deposited in the reactor and is difficult to be detected. The $\mathrm{N}_{\mathrm{Wso}}$ yield increased to $8.0 \%$ when the second stage was heated to $400{ }^{\circ} \mathrm{C}$, slightly increased at $400-550{ }^{\circ} \mathrm{C}$, and significantly increased to $12.6 \%$ at $750{ }^{\circ} \mathrm{C}$. The tendency shows that $\mathrm{TD}$ at $400-550{ }^{\circ} \mathrm{C}$ mainly promotes the formation of $\mathrm{N}_{\mathrm{Wso}}$ and $\mathrm{NH}_{3}$.

The trend in the formation of $\mathrm{HCN}$ is different from that of $\mathrm{NH}_{3}$. Below $550{ }^{\circ} \mathrm{C}, \mathrm{HCN}$ yield is generally low $\left(<3.0 \%\right.$ of $\mathrm{N}_{\mathrm{PC}}$ ), indicating that $\mathrm{TD}$ of $\mathrm{PC}$ volatiles at low temperatures cannot produce significant amount of $\mathrm{HCN}$. $\mathrm{HCN}$ yield increased sharply to $13.9 \%$ by raising temperature to $750{ }^{\circ} \mathrm{C}$. Similar trend was observed in waste pyrolysis [20,21]. Pyrolysis of thermally labile 
nitrogen-containing aliphatic rings can produce methanimine (or can furnish such rings as intermediates), affording relatively high yield of $\mathrm{HCN}$. The temperature of $750{ }^{\circ} \mathrm{C}$ should be favorable for decomposing such compounds.

Consequently, TD of PC volatiles below $750{ }^{\circ} \mathrm{C}$ is not effective for decomposing the entire $\mathrm{NH}_{3}, \mathrm{HCN}$, and $\mathrm{N}_{\text {tar }}$, all of which will be converted to $\mathrm{NO}_{x}$ and $\mathrm{N}_{2} \mathrm{O}$ when the GP is used as fuel. A proper catalyst is required for catalytic reforming $(\mathrm{CR})$ of the volatiles and for reducing the $\mathrm{NO}_{x}$ precursors.

\subsection{Effect of TMCs}

TMCs were widely investigated in biomass and coal gasification [13]. As can be deduced from Fig. 3, the yields of carbon in char $\left(\mathrm{C}_{\text {char }}\right)$ over different catalyst are similar, which should be due to the same pyrolysis temperature of $900{ }^{\circ} \mathrm{C}$ used. The TMCs are active for tar decomposition and their activities at $650{ }^{\circ} \mathrm{C}$ decreased in the order: $\mathrm{Ni} / \mathrm{LYLC}>\mathrm{Ni} / \mathrm{Al}_{2} \mathrm{O}_{3}>$ limonite $>\mathrm{CoMo} / \mathrm{Al}_{2} \mathrm{O}_{3}$. The higher activity of $\mathrm{Ni} / \mathrm{LYLC}$ than $\mathrm{Ni} / \mathrm{Al}_{2} \mathrm{O}_{3}$ is well consistent with the low NPS and high surface area of Ni/LYLC. No carbon in WSO $\left(\mathrm{C}_{\mathrm{WSO}}\right)$ was detected over limonite and NBCs, indicating that all the tarry species from PC pyrolysis can be decomposed at $650{ }^{\circ} \mathrm{C}$. However, $9.7 \%$ and $16.5 \%$ of carbon were found to be deposited on the catalyst and reactor wall $\left(\mathrm{C}_{\text {deposit }}\right)$ over limonite and $\mathrm{Ni} / \mathrm{Al}_{2} \mathrm{O}_{3}$, respectively. Carbon deposition on the catalyst surface was reported to cover the active sites, reduce the surface area, and lead to catalyst deactivation significantly [8]. It is necessary to develop a strategy for avoiding the carbon deposition on the catalyst. Some carbon might also deposit on Ni/LYLC, but it is difficult to determine this part of carbon due to the carbon supporter of the Ni/LYLC. The catalytic activity of $\mathrm{CoMo} / \mathrm{Al}_{2} \mathrm{O}_{3}$ for $\mathrm{CR}$ of PC volatiles is quite low in comparison with limonite and $\mathrm{NBCs}$, although $\mathrm{CoMo} / \mathrm{Al}_{2} \mathrm{O}_{3}$ was reported quite active for hydrodeoxygenation and upgrading of bio-oil [22]. In this case, the carbon balance is $98.4 \%$ and $1.0 \%$ of carbon is in the form of $\mathrm{C}_{\mathrm{WSO}}$. It can be confirmed that $\mathrm{CoMo} / \mathrm{Al}_{2} \mathrm{O}_{3}$ mainly promotes the formation of $\mathrm{C}_{\text {deposit }}(15.7 \%)$. Commercial $\mathrm{CoMo} / \mathrm{Al}_{2} \mathrm{O}_{3}$ showed considerable activity for decomposing natural gas to hydrogen and carbon nanotubes [23]. It is well known that Mo species 
act as a promoter for methane aromatization at elevated temperatures [24]. The arenes produced can act as building units for the growth of carbon nanotubes on the active Co sites [24]. The carbon deposition on the catalyst may lead to the low activity of the $\mathrm{CoMo} / \mathrm{Al}_{2} \mathrm{O}_{3}$ for $\mathrm{PC}$ volatile reforming.

The yield of $\mathrm{N}_{\text {char }}$ is lower than that of $\mathrm{C}_{\text {char }}$, indicating that the release of $\mathrm{N}_{\text {volatile }}$ is more significant than that of carbon. The TMCs, especially NBCs, are active for converting $\mathrm{N}_{\text {volatile }}$ to $\mathrm{N}_{2}$. NBCs proved to be quite active not only for tar reduction, but also for $\mathrm{NH}_{3}$ decomposition (Eq. (3)) [8,13,25]. NBCs were reported to be active for decomposing $\mathrm{NH}_{3}$ even at $400-600{ }^{\circ} \mathrm{C}$ [19]. At the same time, almost no HCN was detected, suggesting that NBCs are active enough for decomposing HCN. HCN can also be converted to $\mathrm{NH}_{3}$ by subsequent reaction with $\mathrm{H}_{2}$ (Eq. (4)) and decomposed to $\mathrm{N}_{2}$ and $\mathrm{C}_{2} \mathrm{H}_{2}$ (Eq. (5)). In this study, almost all the $\mathrm{NH}_{3}, \mathrm{HCN}$, and $\mathrm{N}_{\mathrm{Wso}}$ were converted to $\mathrm{N}_{2}$ over $\mathrm{Ni} / \mathrm{Al}_{2} \mathrm{O}_{3}$, while $92.6 \%$ of $\mathrm{NH}_{3}, 97.3 \%$ of $\mathrm{HCN}$, and all the $\mathrm{N}_{\mathrm{wso}}$ were decomposed to $\mathrm{N}_{2}$ over $\mathrm{Ni} / \mathrm{LYLC}$ at $650{ }^{\circ} \mathrm{C}$.

$$
\begin{aligned}
& 2 \mathrm{NH}_{3} \leftrightarrow \mathrm{N}_{2}+3 \mathrm{H}_{2} \\
& \mathrm{HCN}+3 \mathrm{H}_{2} \leftrightarrow \mathrm{NH}_{3}+\mathrm{CH}_{4} \\
& 2 \mathrm{HCN} \leftrightarrow \mathrm{N}_{2}+\mathrm{C}_{2} \mathrm{H}_{2}
\end{aligned}
$$

Limonite also shows a high activity for the conversion of $\mathrm{N}_{\text {volatile }}$ to $\mathrm{N}_{2}$, which is consistent with catalytic decomposition of $\mathrm{NH}_{3}$ [26] and nitrogen-containing heterocyclic compounds [27] over Fe-based catalysts. However, the nitrogen balance is $83.4 \%$, which is lower than those over NBCs. Tsubouchi et al. [28] reported that metallic Fe formed from limonite achieved the almost complete decomposition of $0.2 \% \mathrm{NH}_{3}$ to $\mathrm{N}_{2}$ at $500{ }^{\circ} \mathrm{C}$. They suggested that the Fe-catalyzed $\mathrm{NH}_{3}$ decomposition proceeded mainly through a cycle mechanism involving $\mathrm{Fe}$ metal and nitrides $\left(\mathrm{Fe}_{3} \mathrm{~N}\right.$ and $\mathrm{Fe}_{4} \mathrm{~N}$ ) (Eqs. (6) and (7)), and the decomposition of Fe nitrides into $\mathrm{N}_{2}$ (Eqs. (8) and (9)) occured below $700{ }^{\circ} \mathrm{C}$. In this study, the limonite used contains large amount of Fe $(65.0 \%$, expressed as metal oxides, as exhibited in Table 2). The NCSs from PC pyrolysis might react with Fe to form Fe nitrides, which should not be completely decomposed at $650{ }^{\circ} \mathrm{C}$, causing a relatively low nitrogen 
balance.

$$
\begin{aligned}
& 8 \mathrm{Fe}+2 \mathrm{NH}_{3} \rightarrow 2 \mathrm{Fe}_{4} \mathrm{~N}+3 \mathrm{H}_{2} \\
& 6 \mathrm{Fe}+2 \mathrm{NH}_{3} \rightarrow 2 \mathrm{Fe}_{3} \mathrm{~N}+3 \mathrm{H}_{2} \\
& 8 \mathrm{Fe}_{3} \mathrm{~N} \rightarrow 6 \mathrm{Fe}_{4} \mathrm{~N}+\mathrm{N}_{2} \\
& 2 \mathrm{Fe}_{4} \mathrm{~N} \rightarrow 8 \mathrm{Fe}+\mathrm{N}_{2}
\end{aligned}
$$

$\mathrm{CoMo} / \mathrm{Al}_{2} \mathrm{O}_{3}$ shows a moderate catalytic activity for converting $\mathrm{NH}_{3}$ and $\mathrm{N}_{\mathrm{WsO}}$ to $\mathrm{N}_{2}$. However, $5.6 \%$ of nitrogen still remained in $\mathrm{NH}_{3}$. Similar to carbon distribution, the nitrogen balance is as low as $79.7 \%$. The nitrogen lost when $\mathrm{CoMo} / \mathrm{Al}_{2} \mathrm{O}_{3}$ was used should be in the form of WISP or deposited on the catalyst. Compared with $\mathrm{Ni}$ - and $\mathrm{Fe}$-based catalysts, $\mathrm{CoMo} / \mathrm{Al}_{2} \mathrm{O}_{3}$ is less active for tar reforming and $\mathrm{NH}_{3}$ decomposition at $650{ }^{\circ} \mathrm{C}$.

\subsection{Effect of $C B C S$}

$\mathrm{CaO}$ and dolomite can lead to tar reduction to a certain extent $[29,30]$. Both catalysts are active for PC tar reduction, as shown in Fig. 3. The decrease in the carbon in gas $\left(\mathrm{C}_{\mathrm{gas}}\right)$ was possibly due to the reaction of $\mathrm{CaO}$ with the $\mathrm{CO}_{2}$ in the GPs. $\mathrm{C}_{\mathrm{gas}}$ was calculated by the sum of the carbon in the carbonaceous gases, i.e., $\mathrm{CO}, \mathrm{CO}_{2}, \mathrm{CH}_{4}$, and gaseous hydrocarbons from $\mathrm{C}_{2}$ to $\mathrm{C}_{4}$.

Different from the TMCs, CBCs are not so active for converting $\mathrm{N}_{\text {volatile }}$ to $\mathrm{N}_{2}$. In contrast, the $\mathrm{NH}_{3}$ yield over the CBCs increased in comparison with that of non-catalytic experiment. As Fig. 3 illustrates, the CBCs significantly promote $\mathrm{HCN}$ and $\mathrm{N}_{\mathrm{WsO}}$ decomposition. The $\mathrm{NH}_{3}$ yield increased from $38.0 \%$ during non-catalytic test to $43.8 \%$ and $62.8 \%$ over $\mathrm{CaO}$ and dolomite, respectively. The results are well consistent with those reported by Leppälahti and colleagues [31], who stated that dolomite was not active for $\mathrm{NH}_{3}$ decomposition, but could reduce the $\mathrm{HCN}$ content via the reactions of Eqs. (10) and (11) in the GPs. Dolomite was found to be less effective for $\mathrm{NH}_{3}$ destruction during coal gasification, but promoted the tar decomposition [30].

$$
\begin{aligned}
& \mathrm{CaO}+2 \mathrm{HCN} \rightarrow \mathrm{CaCN}_{2}+\mathrm{CO}+\mathrm{H}_{2} \\
& \mathrm{CaCN}_{2}+\mathrm{H}_{2} \mathrm{O}+2 \mathrm{H}_{2}+\mathrm{CO}_{2} \rightarrow \mathrm{CaO}+2 \mathrm{NH}_{3}+2 \mathrm{CO}
\end{aligned}
$$

Although the calcined dolomite contains $96.7 \%$ of $\mathrm{CaO}$, as exhibited in Table 2, its catalytic 
activity is different from that of pure $\mathrm{CaO}$. The catalytic activity of dolomite for decomposing $\mathrm{HCN}$ and $\mathrm{N}_{\mathrm{WSO}}$ and producing $\mathrm{NH}_{3}$ is higher than that of $\mathrm{CaO}$. Therefore, dolomite is expected to be more active than $\mathrm{CaO}$ for $\mathrm{PC}$ tar decomposition. As listed in Table 3, the calcined dolomite processes a higher surface area and a smaller pore size, providing more reaction sites for the tar reforming in comparison with $\mathrm{CaO}$. Other metallic oxides in dolomite may also catalyze the tar reforming to a certain extent. The $\mathrm{N}_{2}$ yields obtained over the CBCs are higher than those without catalyst, indicating that the CBCs can also promote the conversion of $\mathrm{N}_{\text {tar }}$ to $\mathrm{N}_{2}$ to a certain extent. Juutilainen et al. [32] found that dolomite is inactive for the conversion of $\mathrm{NH}_{3}$ below $750{ }^{\circ} \mathrm{C}$. In this study, the catalytic temperature was set to $650{ }^{\circ} \mathrm{C}$, which is too low to decompose $\mathrm{NH}_{3}$.

\subsection{Effect of temperature}

$\mathrm{Ni} / \mathrm{Al}_{2} \mathrm{O}_{3}$ and dolomite were employed to further study the effect of temperature on the nitrogen distributions. As shown in Fig. 4, almost neither HCN nor $\mathrm{N}_{\mathrm{WsO}}$ was detected at 400-750 ${ }^{\circ} \mathrm{C}$, suggesting that $\mathrm{Ni} / \mathrm{Al}_{2} \mathrm{O}_{3}$ is active enough for decomposing $\mathrm{N}_{\mathrm{WSO}}$ and $\mathrm{HCN}$ in this temperature range. The high activity of $\mathrm{Ni} / \mathrm{Al}_{2} \mathrm{O}_{3}$ for $\mathrm{HCN}$ decomposition at $400{ }^{\circ} \mathrm{C}$ agrees well with the study by Osińska [33], who demonstrated that a nickel catalyst is active for decomposing HCN. The decomposition of $\mathrm{N}_{\mathrm{WSO}}$ and $\mathrm{HCN}$ over $\mathrm{Ni} / \mathrm{Al}_{2} \mathrm{O}_{3}$ at $400{ }^{\circ} \mathrm{C}$ mainly formed $\mathrm{NH}_{3}$, affording a higher $\mathrm{NH}_{3}$ yield compared to non-catalytic test. However, the activity of $\mathrm{Ni} / \mathrm{Al}_{2} \mathrm{O}_{3}$ for $\mathrm{NH}_{3}$ decomposition is yet quite low at $400{ }^{\circ} \mathrm{C}$. Wang et al. [19] also reported that the activity of a $\mathrm{NBC}$ for $\mathrm{NH}_{3}$ decomposition was negligible at $400{ }^{\circ} \mathrm{C}$. The $\mathrm{NH}_{3}$ yield decreased sharply to $3.7 \%$ by raising temperature to $450{ }^{\circ} \mathrm{C}$ and then decreased to a negligible value above $550{ }^{\circ} \mathrm{C}$. At the same time, the $\mathrm{N}_{2}$ yield increased from $14.9 \%$ to $56.4 \%$ with raising temperature from 400 to $550{ }^{\circ} \mathrm{C}$. The significant increase in $\mathrm{N}_{2}$ yield at $400-450{ }^{\circ} \mathrm{C}$ is predominantly due to the $\mathrm{NH}_{3}$ decomposition. Almost no $\mathrm{NH}_{3}$ and $\mathrm{HCN}$ can be found above $550{ }^{\circ} \mathrm{C}$, indicating that $\mathrm{Ni} / \mathrm{Al}_{2} \mathrm{O}_{3}$ is active enough for $\mathrm{NH}_{3}$ decomposition at $550{ }^{\circ} \mathrm{C}$. The $\mathrm{N}_{2}$ yield increased to $78.8 \%$ when further raising temperature to $750{ }^{\circ} \mathrm{C}$. The main reaction in this temperature range should be the conversion of the nitrogen in WISP or deposited in the reactor form to $\mathrm{N}_{2}$. The results correspond to the previous studies on $\mathrm{NH}_{3}$ 
decomposition from of coal and biomass pyrolysis over supported metals $[8,13,25]$.

The trend in the nitrogen distribution over dolomite is different from that of $\mathrm{Ni} / \mathrm{Al}_{2} \mathrm{O}_{3}$. Data in Fig. 5 show that $\mathrm{NH}_{3}$ is the main NCSs in the temperature range of $450-750{ }^{\circ} \mathrm{C}$. The $\mathrm{NH}_{3}$ yield increased with raising temperature from 450 to $650{ }^{\circ} \mathrm{C}$ and decreased when further raising the temperature to $750{ }^{\circ} \mathrm{C}$. Below $650{ }^{\circ} \mathrm{C}$, dolomite mainly promoted the conversion of $\mathrm{N}_{\mathrm{WsO}}$ to $\mathrm{NH}_{3}$. The decrease in $\mathrm{NH}_{3}$ yield at $750{ }^{\circ} \mathrm{C}$ should be due to the TD of $\mathrm{NH}_{3}$ to $\mathrm{N}_{2}$. Even at $450{ }^{\circ} \mathrm{C}$, dolomite is quite active for reducing HCN. The result is well consistent with the study by Leppälahti and Kurkela [34], who reported that the $\mathrm{CaO}$ in dolomite can react with $\mathrm{HCN}$ to form $\mathrm{NH}_{3}$. Since the $\mathrm{NH}_{3}$ and $\mathrm{HCN}$ are value-added compounds, recovering rather than removing them is more favorable. Isolation of $\mathrm{NH}_{3}$ as a pure compound during $\mathrm{CR}$ of $\mathrm{PC}$ volatiles over dolomite may significantly improve the economic feasibility of the PC gasification process.

\subsection{Effect of steam}

Steam is considered as an efficient method for large-scale $\mathrm{H}_{2}$ production via the reaction of tar with steam and an effective strategy to prevent the carbon deposition and hence the catalyst deactivation. As can be deduced from Fig. 6, no obvious difference can be found between inert and steam reforming of PC volatiles without catalyst, indicating that feeding steam leads to little improvement on non-catalytic reforming of PC volatiles. Different from CR, CSR of PC volatiles over dolomite resulted in a high $\mathrm{HCN}$ yield of $4.4 \%$. As mentioned in Section 3.4, dolomite is quite active for reducing $\mathrm{HCN}$ and negligible of $\mathrm{HCN}$ was produced during $\mathrm{CR}$ over dolomite at $650{ }^{\circ} \mathrm{C}$. Such activity might be affected when steam was introduced. Park et al. [35] reported the suppression of HCN decomposition in the presence of steam for char-steam gasification. Similar to $\mathrm{CR}$, almost all the $\mathrm{N}_{\text {volatile }}$ from PC pyrolysis was converted to $\mathrm{N}_{2}$ over $\mathrm{Ni} / \mathrm{Al}_{2} \mathrm{O}_{3}$. The $\mathrm{N}_{2}$ yield obtained from CSR is higher than that from CR. As mentioned above, some of the $\mathrm{N}_{\mathrm{PC}}$ was found to be deposited on the catalyst surface and reactor during CR. Such $\mathrm{N}_{\mathrm{PC}}$ might be converted to $\mathrm{N}_{2}$ by water-gas shift reactions. Therefore, the steam introduced mainly prevents $\mathrm{HCN}$ decomposition and carbon deposition over dolomite and $\mathrm{Ni} / \mathrm{Al}_{2} \mathrm{O}_{3}$, respectively, at $650{ }^{\circ} \mathrm{C}$. 


\subsection{Nitrogen transformation routes}

As depicted in Fig. 7, the $\mathrm{N}_{\mathrm{PC}}$ was mainly converted to $\mathrm{N}_{\text {tar }}$ and $\mathrm{NH}_{3}$ during pyrolysis, and only small amount of nitrogen is retained as $\mathrm{N}_{\text {char }}$. The secondary thermal decomposition of $\mathrm{N}_{\text {volatile }}$ mainly promotes the conversion of $\mathrm{N}_{\text {tar }}$ to $\mathrm{NH}_{3}$ and the formation of $\mathrm{HCN}$ below and above $650{ }^{\circ} \mathrm{C}$, respectively. However, thermal decomposition of $\mathrm{N}_{\text {volatile }}$ below $750{ }^{\circ} \mathrm{C}$ is insufficient for complete conversion of $\mathrm{N}_{\text {volatile }}$ to $\mathrm{N}_{2}$. During CG, TMCs primarily catalyzes the conversion of $\mathrm{N}_{\text {tar }}$ to $\mathrm{NH}_{3}$ via tar reforming reaction (Eq. (4)). Then the whole $\mathrm{NH}_{3}$ undergoes a catalytic decomposition (Eq. (3)) and is subsequently converted to $\mathrm{N}_{2}$ above $500{ }^{\circ} \mathrm{C}$. The CBCs, especially dolomite, are active for tar reforming and the conversion of the $\mathrm{N}_{\text {tar }}$ to $\mathrm{NH}_{3}$, but not effective for $\mathrm{NH}_{3}$ decomposition. The nitrogen transformation strongly depends on catalyst, temperature, and atmosphere. The activity for $\mathrm{CG}$ over $\mathrm{Ni} / \mathrm{Al}_{2} \mathrm{O}_{3}$ and dolomite can be significantly promoted when raising the temperature from 450 to $750{ }^{\circ} \mathrm{C}$. The steam introduced can prevent the activity for $\mathrm{HCN}$ decomposition over dolomite and carbon deposition on the NBC.

\section{Conclusions}

$\mathrm{N}_{\mathrm{PC}}$ was mainly converted to $\mathrm{NH}_{3}, \mathrm{HCN}, \mathrm{N}_{2}$, and $\mathrm{N}_{\mathrm{WSO}}$, and their yields increased with raising temperature to $650{ }^{\circ} \mathrm{C} . \mathrm{NH}_{3}$ is the main nitrogenous gas under inert conditions used in this investigation. TD at $750{ }^{\circ} \mathrm{C}$ mainly led to $\mathrm{NH}_{3}$ decomposition and $\mathrm{HCN}$ formation. TD of the PC volatiles below $750{ }^{\circ} \mathrm{C}$ is less effective for removing the entire $\mathrm{NO}_{x}$ precursors. TMCs, especially NBCs, are quite active for converting $\mathrm{N}_{\text {volatile }}$ to $\mathrm{N}_{2}$, while the CBCs, especially dolomite, effectively catalyzed the conversion of $\mathrm{N}_{\text {volatile }}$ to $\mathrm{NH}_{3}$ at $650{ }^{\circ} \mathrm{C}$. $\mathrm{Ni} / \mathrm{Al}_{2} \mathrm{O}_{3}$ demonstrated excellent activity for the decomposition of $\mathrm{NH}_{3}$ and $\mathrm{HCN}$ to $\mathrm{N}_{2}$ at $550{ }^{\circ} \mathrm{C}$. Dolomite effectively improved the conversion of $\mathrm{HCN}$ and $\mathrm{N}_{\mathrm{WSO}}$ to $\mathrm{NH}_{3}$ at $650{ }^{\circ} \mathrm{C}$. Steam introduced mainly prevents $\mathrm{HCN}$ decomposition and coke deposition over dolomite and $\mathrm{Ni} / \mathrm{Al}_{2} \mathrm{O}_{3}$, respectively.

\section{Acknowledgements}

This work was subsidized by the National Natural Science Foundation of China (Grants 21206189 and 21306224), the Fundamental Research Funds for the Central Universities (China University of 
312 Mining \& Technology; Grants 2012QNA15 and 2012QNA18), the Science and Technology Project

313 of Xuzhou (XM13B106), the Natural Science Foundation of China for Innovative Research Group

314 (Grant 51221462), the Priority Academic Program Development of Jiangsu Higher Education

315 Institutions, the Advanced Low Carbon Technology Research and Development Program (ALCA)

316 from Japan Science and Technology Agency and the Strategic Chinese-Japanese Joint Research

317 Program (Grant 2013DFG60060).

$318 \quad$ Nomenclature

\begin{tabular}{|c|c|}
\hline CBCs & Ca-based catalysts \\
\hline $\mathrm{C}_{\text {char }}$ & carbon in char \\
\hline $\mathrm{C}_{\text {deposit }}$ & carbon deposited on the catalyst and reactor wall \\
\hline CG & catalytic gasification \\
\hline $\mathrm{C}_{\text {gas }}$ & carbon in gas \\
\hline $\mathrm{CR}$ & catalytic reforming \\
\hline $\mathrm{C}_{\mathrm{WSO}}$ & carbon in WSO \\
\hline DIW & deionized water \\
\hline GPs & gaseous products \\
\hline $\mathrm{HCV}$ & high calorific value \\
\hline LSM & livestock manure \\
\hline NBCs & Ni-based catalysts \\
\hline $\mathrm{N}_{\text {char }}$ & in char \\
\hline NCSs & nitrogen-containing species \\
\hline $\mathrm{N}_{\mathrm{PC}}$ & nitrogen in $\mathrm{PC}$ \\
\hline NPSs & Ni particle sizes \\
\hline $\mathrm{N}_{\mathrm{tar}}$ & nitrogen in tar \\
\hline $\mathrm{N}_{\text {volatile }}$ & nitrogen in volatiles \\
\hline $\mathrm{N}_{\text {WSO }}$ & nitrogen in WSO \\
\hline $\mathrm{PC}$ & pig compost \\
\hline RT & room temperature \\
\hline TD & thermal decomposition \\
\hline TMCs & transition metal catalysts \\
\hline $\mathrm{TN}$ & total nitrogen \\
\hline TOC & total organic carbon \\
\hline TSFBQR & two-stage fixed-bed quartz reactor \\
\hline WISP & water-insoluble portion \\
\hline WSO & water-soluble oil \\
\hline
\end{tabular}


XRD

X-ray diffraction

\section{References}

[1] Ro KS, Cantrell K, Elliott D, Hunt PG. Catalytic wet gasification of municipal and animal wastes. Ind Eng Chem Res 2007;46:8839-45.

[2] Shinogi Y, Kanri Y. Pyrolysis of plant, animal and human waste: physical and chemical characterization of the pyrolytic products. Bioresour Technol 2003;90:241-7.

[3] Cantrell KB, Ducey T, Ro KS, Hunt PG. Livestock waste-to-bioenergy generation opportunities. Bioresour Technol 2008;99:7941-53.

[4] McKendry P. Energy production from biomass (part 3): gasification technologies. Bioresour Technol 2002;83:55-63.

[5] Xu G, Murakami T, Suda T, Matsuzaw Y, Tani H. Two-stage dual fluidized bed gasification: its conception and application to biomass. Fuel Process Technol 2009;90:137-44.

[6] Xiao XB, Cao JP, Meng XL, Le DD, Li LY, Ogawa Y, et al. Synthesis gas production from catalytic gasification of waste biomass using nickel-loaded brown coal. Fuel 2013;103:135-40.

[7] Zhang SY, Wang XJ, Cao JP, Takarada T. Low temperature catalytic gasification of pig compost to produce $\mathrm{H}_{2}$ rich gas. Bioresour Technol 2011;102:2033-9.

[8] Cao JP, Shi P, Zhao XY, Wei XY, Takarada T. Catalytic reforming of volatiles and nitrogen compounds from sewage sludge pyrolysis to clean hydrogen and synthetic gas over a nickel catalyst. Fuel Process Technol 2014;123:34-40.

[9] Cao JP, Shi P, Zhao XY, Wei XY, Takarada T. Decomposition of $\mathrm{NO}_{x}$ Precursors during gasification of wet and dried pig manures and their composts over Ni-based catalysts. Energy Fuels 2014;28:2041-6.

[10] Wang J, Xiao B, Liu S, Hu Z, He P, Guo D, et al. Catalytic steam gasification of pig compost for hydrogen-rich gas production in a fixed bed reactor. Bioresour Technol 2013;133:127-33. 
[11] Cao JP, Xiao XB, Zhang SY, Zhao XY, Sato K, Ogawa Y, et al. Preparation and characterization of bio-oils from internally circulating fluidized-bed pyrolysis of municipal, livestock and wood waste. Bioresour Technol 2011;102:2009-15.

[12] Cao JP, Li LY, Morishita K, Xiao XB, Zhao XY, Wei XY, et al. Nitrogen transformations during fast pyrolysis of sewage sludge. Fuel 2013;104:1-6.

[13] Xu C, Donald J, Byambajav E, Ohtsuka Y. Recent advances in catalysts for hot-gas removal of tar and $\mathrm{NH}_{3}$ from biomass gasification. Fuel 2010;89:1784-95.

[14] Furusawa T, Tsutsumi A. Development of cobalt catalysts for the steam reforming of naphthalene as a model compound of tar derived from biomass gasification. Appl Catal A 2005;278:195-205.

[15] Li LY, Morishita K, Mogi H, Yamasaki K, Takarada T. Low-temperature gasification of a woody biomass under a nickel-loaded brown coal char. Fuel Process Technol 2010;91:889-94.

[16] Cao JP, Huang X, Zhao XY, Wang BS, Meesuk S, Sato K, Wei XY, Takarada T. Low-temperature catalytic gasification of sewage sludge-derived volatiles to produce clean $\mathrm{H}_{2}$-rich syngas over a nickel loaded on lignite char. Int J Hydrogen Energy 2014;39:9193-9.

[17] Witoon T. Characterization of calcium oxide derived from waste eggshell and its application as $\mathrm{CO}_{2}$ sorbent. Ceram Int 2011;37: 3291-8.

[18] Hanssona K-M, Åmanda LE, Habermannb A, Winter F. Pyrolysis of poly-Lleucine under combustion-like conditions. Fuel 2003;82:653-60.

[19] Wang W, Padban N, Ye Z, Andersson A, Bjerle I. Kinetics of ammonia decomposition in hot gas cleaning. Ind Eng Chem Res 1999;38:4175-82.

[20] Tian FJ, Li BQ, Chen Y, Li CZ. Formation of $\mathrm{NO}_{x}$ precursors during the pyrolysis of coal and biomass. Part V. Pyrolysis of a sewage sludge. Fuel 2002;81:2203-8.

[21] Fullana A, Conesa JA, Font R, Martín-Gullón I. Pyrolysis of sewage sludge: nitrogenated compounds and pretreatment effects. J Anal Appl Pyrol 2003;68-69:561-75.

[22] Bu Q, Lei H, Zacher AH, Wang L, Ren S, et al. A review of catalytic hydrodeoxygenation of 
lignin-derived phenols from biomass pyrolysis. Bioresour Technol 2012;124:470-7.

[23] Awadallah AE, Aboul-Enein AA, Aboul-Gheit AK. Effect of progressive Co loading on commercial $\mathrm{Co}-\mathrm{Mo} / \mathrm{Al}_{2} \mathrm{O}_{3}$ catalyst for natural gas decomposition to $\mathrm{CO}_{x}$-free hydrogen production and carbon nanotubes. Energ Convers Manage 2014;77:143-51.

[24] Aboul-Gheit AK, Awadallah AE, Aboul-Enein AA, Mahmoud AH. Molybdenum substitution by copper or zinc in H-ZSM-5 zeolite for catalyzing the direct conversion of natural gas to petrochemicals under non-oxidative conditions. Fuel 2011;90:3040-6.

[25] Donald J, Xu C, Hashimoto H, Byambajav E, Ohtsuka Y. Novel carbon-based Ni/Fe catalysts derived from peat for hot gas ammonia decomposition in an inert helium atmosphere. Appl Catal A 2010;375:124-33.

[26] Min Z, Lin JY, Yimsiri P, Asadullah M, Li C-Z. Catalytic reforming of tar during gasification. Part V. Decomposition of $\mathrm{NO}_{x}$ precursors on the char-supported iron catalyst. Fuel 2014;116:19-24.

[27] Matsuyama T, Tsubouchi N, Ohtsuka Y. Catalytic decomposition of nitrogen-containing heterocyclic compounds with highly dispersed iron nanoparticles on carbons. J Mol Catal A Chem 2012;356:14-9.

[28] Tsubouchi N, Hashimoto H, Ohtsuka Y. High catalytic performance of fine particles of metallic iron formed from limonite in the decomposition of a low concentration of ammonia. Catal Lett 2005; 105:203-8.

[29] Jeremiáš M, Pohořelý $M$, Bode P, Skoblia S, Beňo Z, Svoboda K. Ammonia yield from gasification of biomass and coal in fluidized bed reactor. Fuel 2014;117: 917-25.

[30] Pinto F, Lopes H, André R N, Gulyurtlu I, Cabrita I. Effect of catalysts in the quality of syngas and by-products obtained by co-gasification of coal and wastes. 1. Tars and nitrogen compounds abatement. Fuel 2007;86:2052-63.

[31] Leppälahti J, Simell P, Kurkela E. Catalytic conversion of nitrogen compounds in gasification gas. Fuel Process Technol 1991;29:43-56. 
[32] Juutilainen SJ, Simell PA, Krause AO. Zirconia: Selective oxidation catalyst for removal of tar and ammonia from biomass gasification gas. Appl Catal B 2006;62:86-92.

[33] Osińska M. Decomposition of gaseous $\mathrm{HCN}$ in the presence of Ni-containing catalysts. React Kinet Mech Cat 2013;109:57-65.

[34] Leppälahti J, Kurkela E. Behaviour of nitrogen compounds and tars in fluidized bed air gasification of peat. Fuel 1991;70:491-7.

[35] Park DC, Day S J, Nelson P F. Formation of $N$-containing gas-phase species from char gasification in steam. Fuel 2008;87:807-14.

\section{Figure captions}

Table 1 Characteristics of the PC sample.

Table 2 Chemical composition (wt.\%) of the limonite and calcined dolomite.

Table 3 Main characteristics of the catalysts.

Fig. 1. XRD patterns of the TMCs and CBCs.

Fig. 2. Effect of temperature on nitrogen distributions during TD of PC volatiles.

Fig. 3. Effect of catalyst on carbon and nitrogen distributions.

Fig. 4. Effect of temperature on nitrogen distributions over $\mathrm{Ni} / \mathrm{Al}_{2} \mathrm{O}_{3}$.

Fig. 5. Effect of temperature on nitrogen distributions over dolomite.

Fig. 6. Effect of steam on nitrogen distributions over dolomite and $\mathrm{Ni} / \mathrm{Al}_{2} \mathrm{O}_{3}$.

Fig. 7. Proposed nitrogen transformation routes during CG of PC volatiles. 


\section{Table 1}

Characteristics of the PC sample.

\begin{tabular}{|c|c|c|c|c|c|c|c|c|}
\hline \multicolumn{3}{|c|}{ Proximate analysis $(\mathrm{wt} . \%, \mathrm{~d})^{\mathrm{a}}$} & \multicolumn{4}{|c|}{ Ultimate analysis (wt.\%, daf) } & \multirow{2}{*}{$\begin{array}{l}\mathrm{S}_{\mathrm{t}, \mathrm{d}} \\
(\mathrm{wt} . \%)\end{array}$} & \multirow{2}{*}{$\begin{array}{l}\mathrm{HCV} \\
(\mathrm{MJ} / \mathrm{kg})\end{array}$} \\
\hline $\mathrm{M}_{\mathrm{ar}}$ & $\mathrm{A}_{\mathrm{d}}$ & $\mathrm{VM}_{\mathrm{daf}}$ & $\mathrm{C}$ & $\mathrm{H}$ & $\mathrm{N}$ & $\mathrm{O}^{b}$ & & \\
\hline 27.6 & 19.2 & 81.8 & 49.3 & 6.8 & 5.1 & $>38.1$ & 0.7 & 15.9 \\
\hline
\end{tabular}

$\mathrm{M}_{\mathrm{ar}}$ : moisture (received basis); $\mathrm{A}_{\mathrm{d}}$ : ash (dried basis); $\mathrm{FC}_{\mathrm{daf}}$ : fixed carbon (dried and ash-free basis); $\mathrm{VM}_{\text {daf }}$ : volatile matter (dried and ash-free basis); d: dried basis; daf: dried and ash-free basis; $S_{\mathrm{t}, \mathrm{d}}$ : total sulfur in dried basis. ${ }^{b}$ Calculated by difference. 


\section{Table 2}

Chemical composition (wt.\%) of the limonite and calcined dolomite.

\begin{tabular}{lllllllll}
\hline Sample & $\mathrm{Fe}_{2} \mathrm{O}_{3}$ & $\mathrm{SiO}_{2}$ & $\mathrm{Al}_{2} \mathrm{O}_{3}$ & $\mathrm{NiO}$ & $\mathrm{Co}_{2} \mathrm{O}_{3}$ & $\mathrm{Cr}_{2} \mathrm{O}_{3}$ & $\mathrm{CaO}$ & $\mathrm{MgO}$ \\
\hline Limonite & 65.00 & 1.67 & 11.24 & 1.69 & 0.13 & 1.70 & 0.07 & 0.25 \\
Calcined dolomite & 0.12 & 0.38 & 0.23 & & & & 96.7 & 0.32 \\
\hline
\end{tabular}




\section{Table 3}

Main characteristics of the catalysts.

\begin{tabular}{lllll}
\hline Catalyst & Average pore size $(\mathrm{nm})$ & BET surface area $\left(\mathrm{m}^{2} / \mathrm{g}\right)$ & Loading $(w t . \%)$ & NPS $(\mathrm{nm})$ \\
\hline $\mathrm{Ni} / \mathrm{Al}_{2} \mathrm{O}_{3}$ & 9.2 & 104 & $\mathrm{Ni}: 20 \pm 2$ & 10.3 \\
$\mathrm{Ni} / \mathrm{LYLC}$ & 3.0 & 348 & $\mathrm{Ni}: 9 \pm 1$ & 6.9 \\
Limonite & 9.4 & 149 & & \\
Reduced limonite & 16.6 & 46 & $\mathrm{CoO}: 3.0-4.0, \mathrm{MoO}_{3}: 13.0-15.0$ & \\
$\mathrm{CoMo} / \mathrm{Al}_{2} \mathrm{O}_{3}$ & 9.1 & 230 & & \\
$\mathrm{Calcined}$ dolomite & 24.8 & 29 & & \\
$\mathrm{CaO}$ & 37.6 & 11.6 & & \\
$\mathrm{Sand}$ & 15.8 & 1.7 & & \\
\hline
\end{tabular}



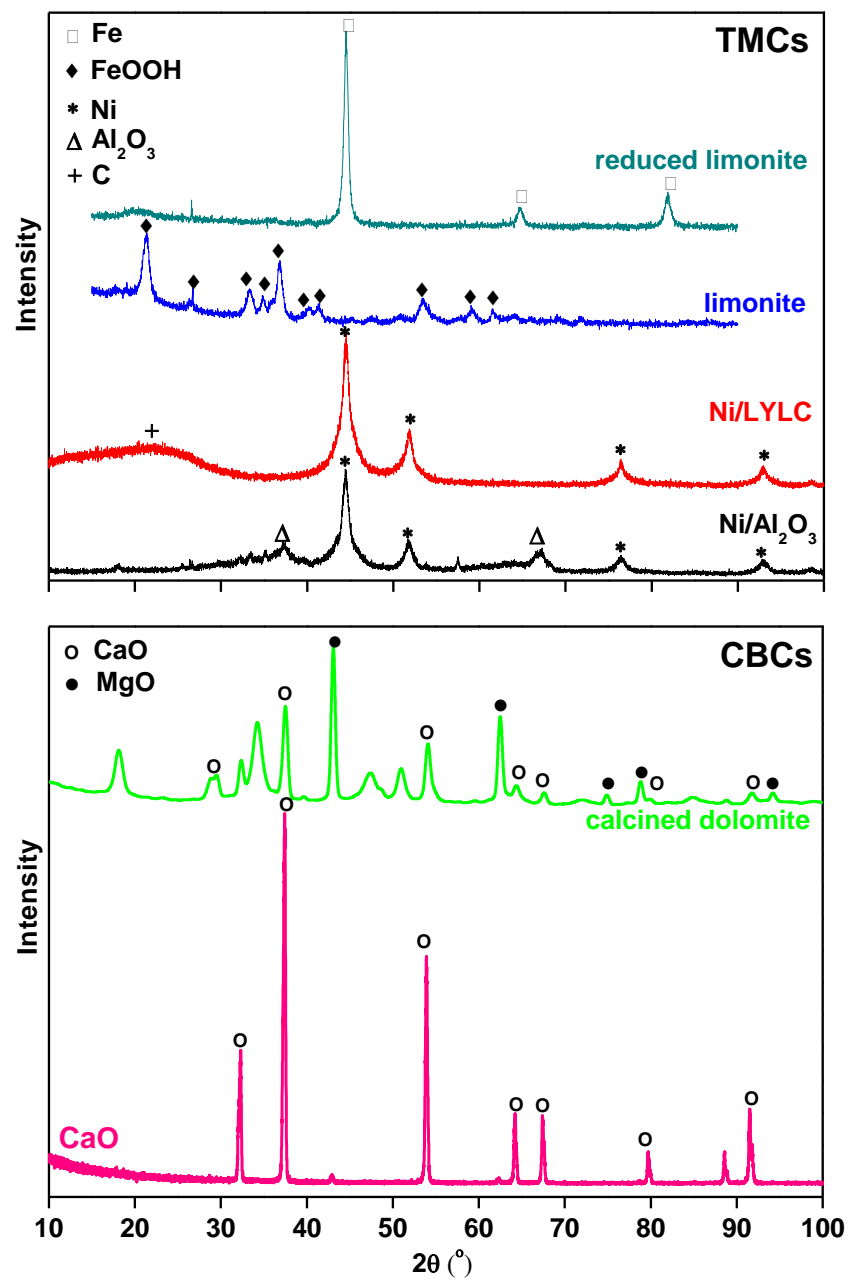

Fig. 1. XRD patterns of the TMCs and CBCs. 
Figure 1 (black and white)
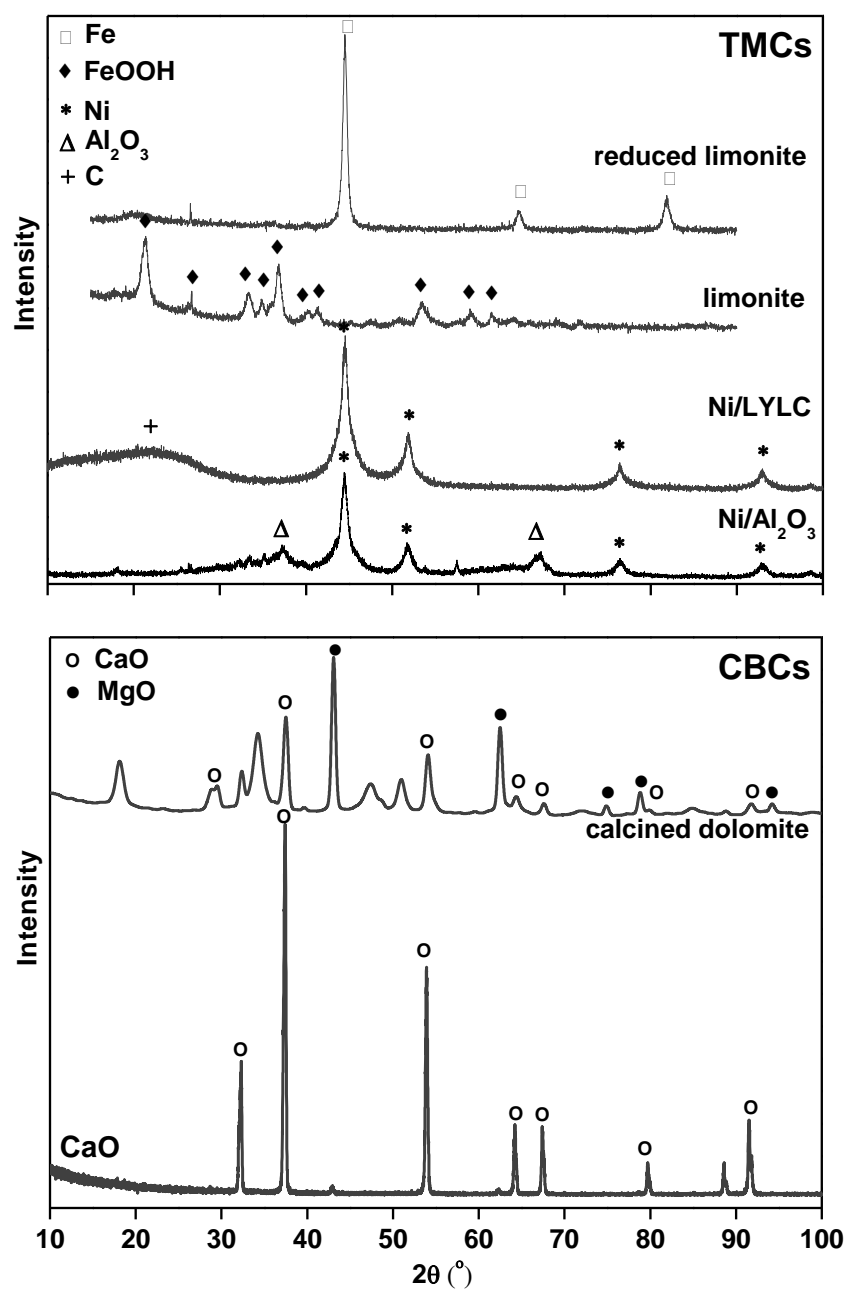

Fig. 1. XRD patterns of the TMCs and CBCs. 


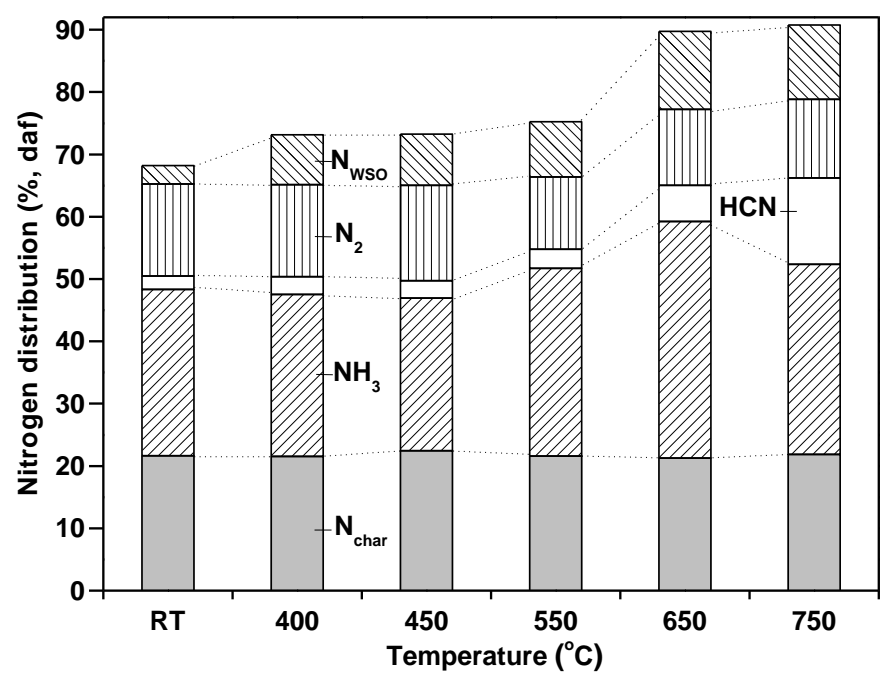

Fig. 2. Effect of temperature on nitrogen distributions during TD of PC volatiles. 

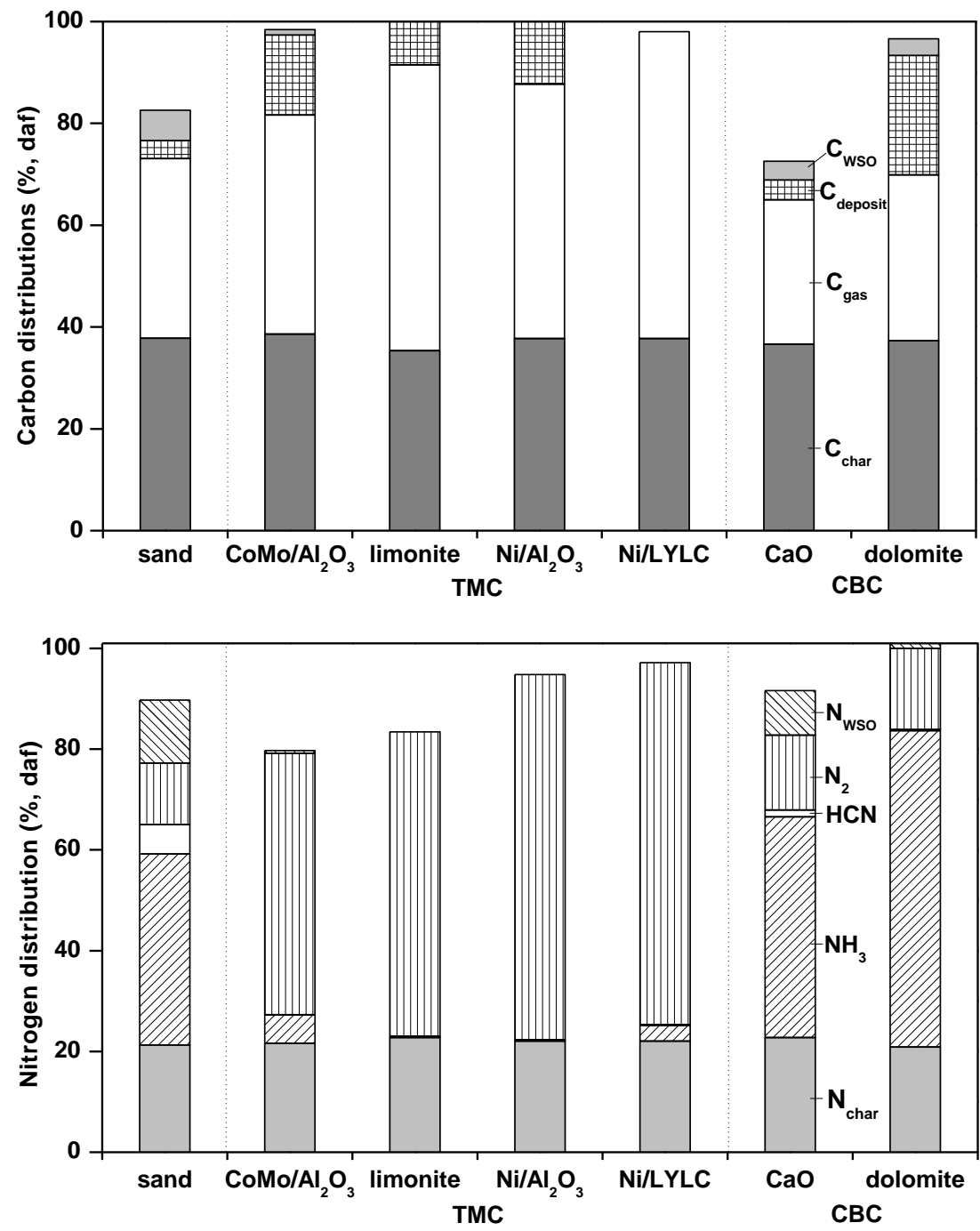

Fig. 3. Effect of catalyst on carbon and nitrogen distributions. 


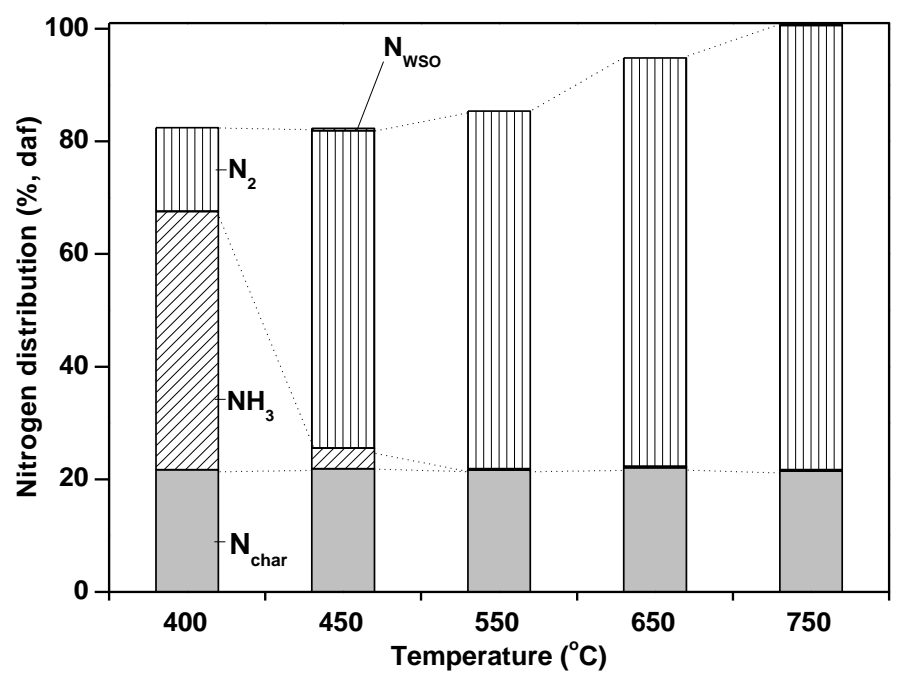

Fig. 4. Effect of temperature on nitrogen distributions over $\mathrm{Ni} / \mathrm{Al}_{2} \mathrm{O}_{3}$. 


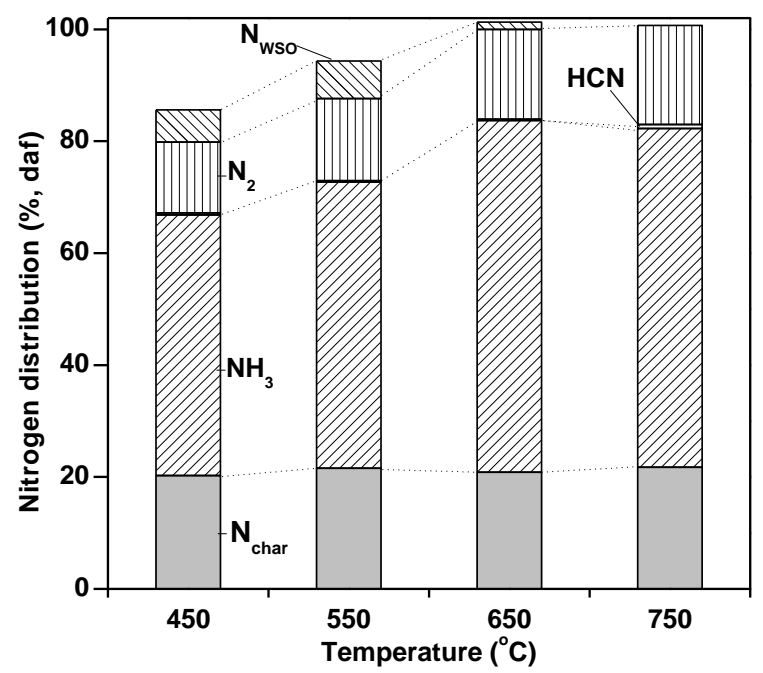

Fig. 5. Effect of temperature on nitrogen distributions over dolomite. 


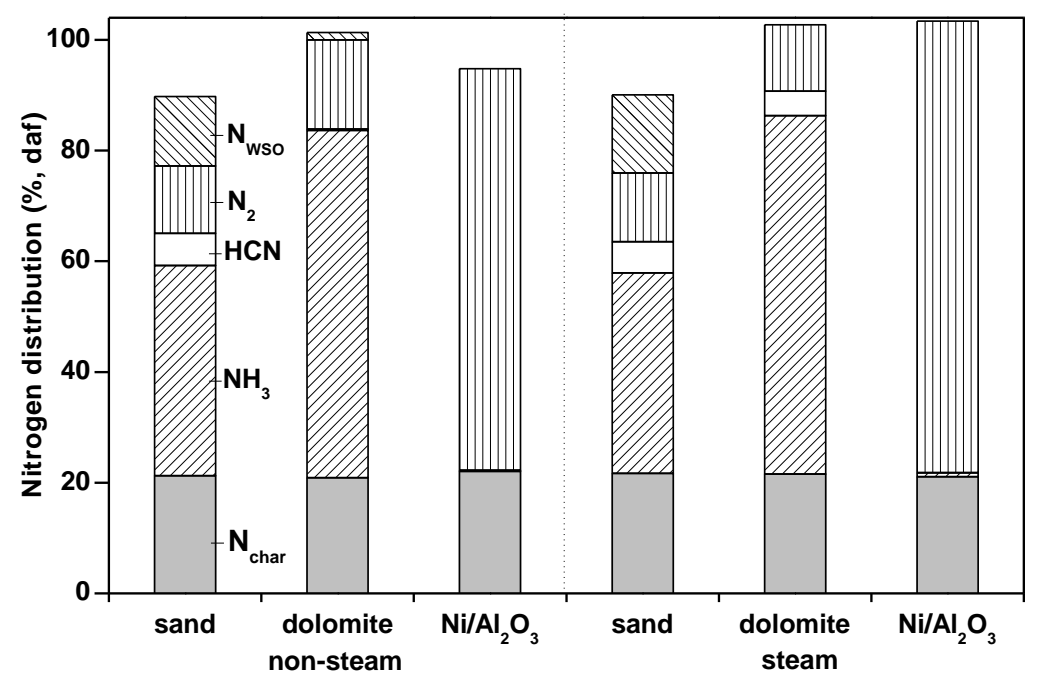

Fig. 6. Effect of steam on nitrogen distributions over dolomite and $\mathrm{Ni} / \mathrm{Al}_{2} \mathrm{O}_{3}$. 
Figure 7 color

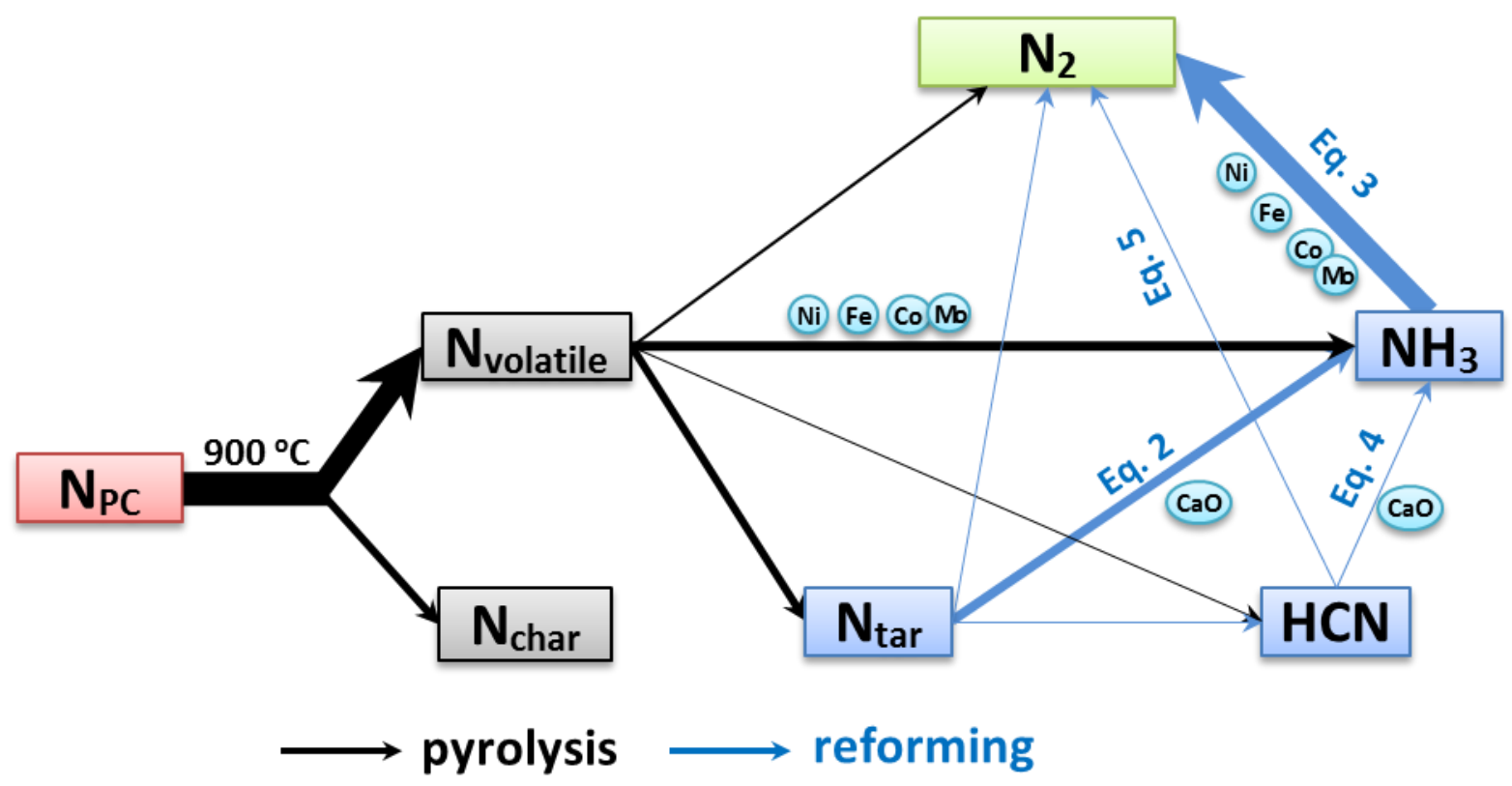

Fig. 7. Proposed nitrogen transformation routes during CG of PC volatiles. 
Figure 7 black and white

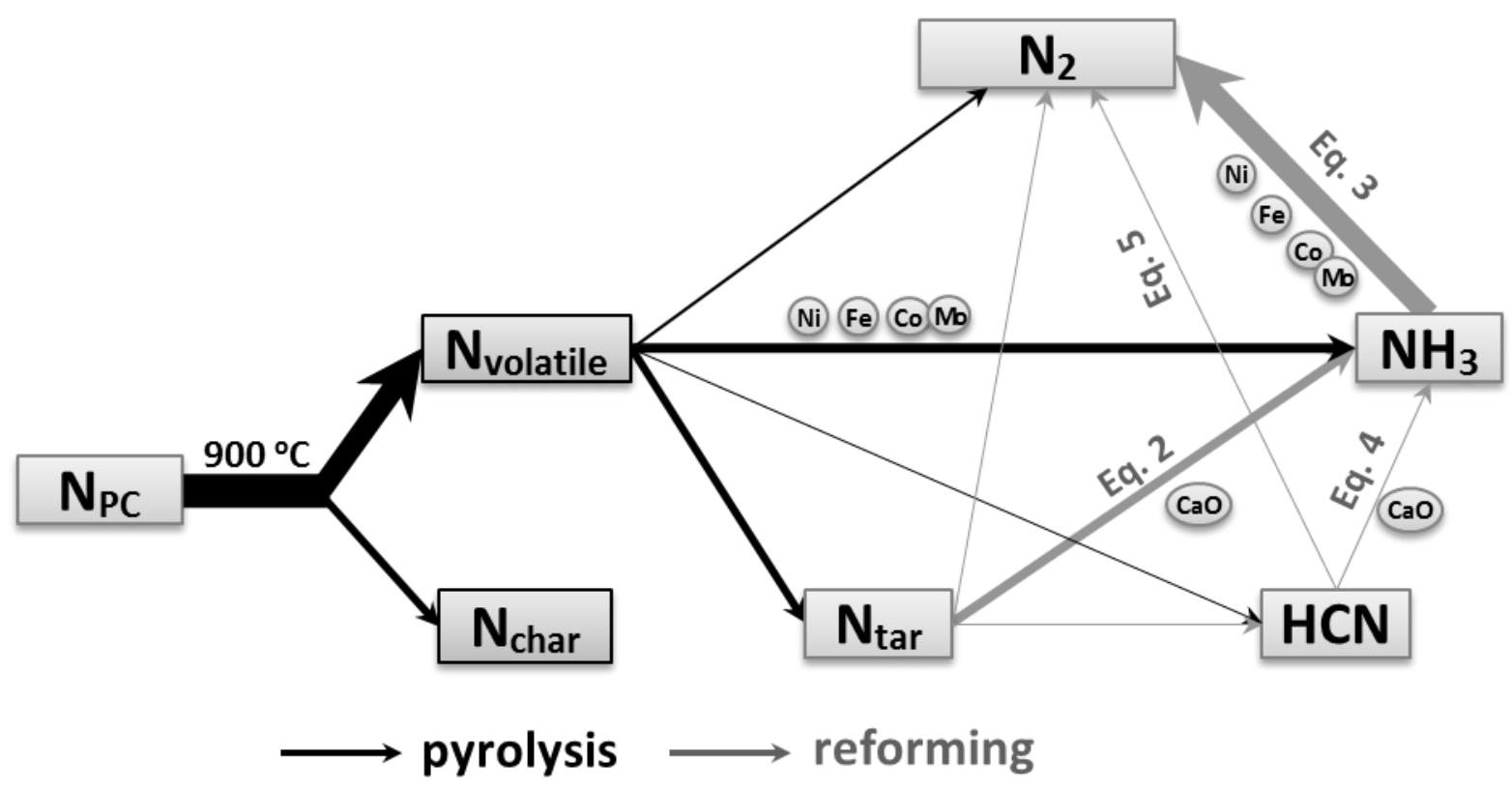

Fig. 7. Proposed nitrogen transformation routes during CG of PC volatiles. 